\title{
CORRELATION OF FINANCIAL STATEMENT COMPONENTS IN DETECTING FINANCIAL FRAUD
}

\author{
Handayani \\ Tarjo \\ Yuni Rimawati \\ Faculty of Economics and Business \\ Trunojoyo University. Madura \\ Email:Rs.handayani@yahoo.co.id
}

\author{
ARTICLE INFORMATION \\ Article history: \\ Received April 13, 2016 \\ Revised June 05, 2016 \\ Accepted June27, 2016 \\ JEL Classifications \\ M41

\section{Key Words:} \\ Absence of Correlation of \\ Financial Statement Components, \\ Red Flags, Fraud.
}

\section{DOI:}

10.21532/apfj.001.16.01.02.22

\begin{abstract}
The purpose of this study is to determine the absence of correlation offinancial statement components as red flags in detecting financial statement fraud. The sampling in this study is done using purposive sampling technique. There are two categories of companies used as the study sample:fraud companies and non-fraud companies. Fraud companies are the companies that get sanction from Capital Market Supervisory Agency (Bapepam) andFinancial Services Authority (OJK) period 2000-2014, while nonfraud companies are selected with the criteria: having equivalent assets, engaging in the same industry, and using the same financial statements as the financial statements used by the fraud companies. The total samples of this study are 122 companies consisting of 61 fraud companies and 61 non-fraud companies. Spearman correlation test is used to answer the research hypothesis. The conclusions of this study are (1) the absence of correlation between cash flows andearnings can be usedas red flags to detect fraud, (2) the existence of correlation between receivables and revenues cannot be used as red flags to detect fraud, (3) the existence of correlation between allowances for uncollectible accounts and receivable cannot be used as red flags to detect fraud.
\end{abstract}

\section{Keywords:}

\section{INTRODUCTION}

Fraud scandals in financial reporting have recently been an endless discussion. The emergence of such big 
scandals does not make new players afraid to follow the footsteps of their predecessor. The most scandalous case was Enron case in 2001 that eventually prompted some policy makers to set new regulations, such as SOX (SarbanesOxley Act), ISA 240 (International Standard on Auditing), and SAS 99 (Statement on Auditing Standards). Enron case has become a heavy blow to the world of investment, where many people were starting to doubt the credibility of the capital market.

In the last two decades, financial statement fraud has increased substantially (Rezaee: 2010). This is justified in Global Fraud Study conducted by the Association of Certified Fraud Examiners (2012) that loss due to financial statement fraud in 2008 was amounted to $\$ 2$ million. In 2010 it increased to $\$ 4.1$ million. This proves that the level of fraud in financial reporting has been getting higher year by year. Financial statement frauds have also occurred in Indonesia, especially those performed by public companies. It is based on the number of sanctions provided by Bapepam (Capital Market Supervisory Agency) and OJK (Financial Services Authority) for violations of the regulations in the capital market. Table 1.1 shows that within the period of 14 years there were still many companies that deliberately manipulated the financial statements with the aim to benefit certain parties. In such a considerable period of time, the regulators should have been able to minimize the existing violations. Here is the number of violations of capital market regulations committed by public companies in Indonesia:
Table 1.1

\section{TheNumber of Violations of Regulations in the Indonesian Stock Exchange (IDX)}

\begin{tabular}{|l|l|l|l|}
\hline Year & $\begin{array}{l}\text { Number of } \\
\text { Violations }\end{array}$ & Year & $\begin{array}{l}\text { Number of } \\
\text { Violations }\end{array}$ \\
\hline 2000 & 304 & 2008 & 165 \\
\hline 2001 & 153 & 2009 & 276 \\
\hline 2002 & 246 & 2010 & 222 \\
\hline 2003 & 83 & 2011 & 168 \\
\hline 2004 & 313 & 2012 & 302 \\
\hline 2005 & 393 & 2013 & 339 \\
\hline 2006 & 193 & 2014 & 259 \\
\hline 2007 & 203 & & \\
\hline
\end{tabular}

Source: Processed data of Bapepamand OJK 2000-20014

According to SA (Auditing Standards) section 110 of the Statement on Auditing Standards (PSA) No. 01, an auditor is responsible to plan and perform audit in order to obtain reasonable assurance about whether the financial statements are free from material misstatements caused by either error or fraud. Not all financial statements which have been audited are free from material misstatements, for example, the cases occurring in major companies (Enron, Word Com, Merck, Kingston Catton, Walt Disney, Kimia Farma, Indofarma, andSetyam). Although their financial statements had been audited by external auditors, or even some of them had employed the services of the big four accounting firms, there still occurred material misstatements which werecharacterized by a fraud. In carrying out the audit, an auditor is required to be observant to catch early warning signs (red flags). Red flags could be an indicator of something that requires further 
investigation. Auditor's proficiency in reading and understanding the signs of danger will increase the possibility to detect financial statement fraud. Red flags are important in auditing process so that the scandals of fraud would not happen anymore.

Fraud, according to SAS No. 99, is a deliberate action to produce material misstatementinfinancial statements that become the audit subject. The research conducted by ACFE in 2014 found that based on the cases of fraud from fraud tree, the most common type of fraud is the asset misappropriation $(85.4 \%)$, followed by corruption (36.8\%), and fraudulent statements (9\%). However, financial statement fraud was the one that caused the biggest loss, reaching \$ 1 million. Even the research results of ACFE in 2014 were not much different from those in 2002 stating that financial statement fraud caused a loss up to $\$ 4.25$ million, whereas the percentage of financial statement fraud was only $5 \%$ of the type of fraud occurring. The following table shows the research results of Association of Certified Fraud Examiners (ACFE) 2014 on fraud occurring within the scope of the fraud tree.

\section{Table 1.2}

Fraudsof theFraud Tree

\begin{tabular}{lllllll}
\hline \multirow{2}{*}{ Fraud Tree } & \multicolumn{3}{c}{$\begin{array}{c}\text { Percentage of the } \\
\text { Occurrence of Fraud } \\
\end{array}$} & \multicolumn{7}{c}{ Tree } & & \multicolumn{2}{c}{ Loss } & \\
\cline { 2 - 7 } Corruption & 2010 & 2012 & 2014 & 2010 & 2012 & 2014 \\
Asset Misappropriation & $32.8 \%$ & $86.7 \%$ & $85.4 \%$ & $\$ 135,000$ & $\$ 120.00$ & $\$ 130,000$ \\
Financial Statment Fraud & $4.8 \%$ & $7.6 \%$ & $9.9 \%$ & $\$ 4,100,000$ & $\$ 1,000,000$ & $\$ 1,000,000$ \\
\hline
\end{tabular}

Source: Processed data of ACFE 2014

The research conducted by ACFEdescribes a major impact of financial statement fraud losses. So, it is necessary to prevent or detect fraud which would be a major scandal that hurt many parties. Wuerges 2008 in Nugraha (2015: 32) conducted a study and found that the undetected fraud cases in the majority of companies in the United States were 96.80\%, meaning that only $3.2 \%$ of fraud was able to be disclosed by SEC.

The commitment of management and internal company in providing transparent, accurate, and non-misleading information to investors is a form of good corporate governance. The most responsible party to implement good corporate governance is the company's top management who is authorized to determine the policy and to implement the policy. But if it is associated with agency theory, where each party has a great conflict of interest, the manager, as the party in charge of managing the company, sometimes provides information that is not symmetrical with the actual state of the company. This information 
is usually in the form of financial statements consisting of "number games", or better known as earnings management.

The asymmetry of information whichusually causes earnings management actions is actually legitimate as long as the earnings management is done within the limits of GAAP (Generally Accepted Accounting Principles). Healy (1999) mentions that earnings management is the management creativity in preparing financial statements and arranging transactions to alter financial statements with the aim of giving a certain impression to influence the actions of the users of the financial statements. It can be concluded that earnings management can make the financial statements unqualified, because the qualitative characteristics of the financial statements may not be fulfilled.

For business people, earnings management actually leads to a negative action. Mulford and Comiskey (2010) say that academic community assumes that earnings management in financial statements is a good action or not bad, but practitioners and regulators believe that earnings management will create problems that may have an impact everywhere. This is reinforced by the opinion of Rezaee (2010: 8) that financial statement fraud is often preceded by misstatements or earnings management of the quarterly financial report, which is considered immaterial, but eventually grows into a fraud on a large scale and produce misleading annual financial statements.

Some fraud scandals in financial statements begin from earnings management, for instance, in the case of HealthSouth that inflated profit of \$ 1.4 billion, Enron scandal in the US, as well as Satyan, an Indian company, that also committed fraud in their financial statements by inflating the earnings of $\$ 1.5$ billion. Fraud scandals also occurred in Indonesia beginning from the earnings management practices as in the case of PT Kimia Farma, in which based on the inspection of Bapepam 2002, it was found evidence that the earnings ended on December 31, 2001 were reported overstated of IDR 32.7 billion. Similarly, PT Indofarma was sanctioned byBapepam in 2004 because the company reported overstated inventories of IDR 28.87 billion and understated cost of goods sold of IDR 28.8 billion and overstated earnings of Rp28.8 billion. Such cases really shocked the businesses of capital markets, and this proves that financial statement fraud has a close relationship with earnings management. In Mulford and Comiskey (2010), AAER (Accounting and Auditing Enforcement Releases) conducted research only in 2000 and found many cases of fraud beginning with the earnings management practices, as occurredat Initile Design, System Software Associates, ABS Industries, Sirena Apparel, and Guilford Mills.

\section{SEC (Securities and Exchange Commission)} divides earnings management into two groups, namely earnings management for good business practices and earnings management for abusive earnings management. To find the practice of abusive earnings management in a company, Magrath and Weld (2002) mention early warning signs that can be used to sniff out whether the company plays some 
of its accounts to action that leads to fraud. The early warning signs to detect abusive earnings management practices, used in this study, are the cash flows that are not correlated with earnings, the receivables that are not correlated with revenue, and the allowance for doubtful accounts that are not correlated with the receivables. The uncorrelated accounts are strongly suspected to be a sign that the company tries to manipulate the figures in the financial statements. Some researches on financial statement fraud have been done before, but what makes this study different from the previous researches is the testing of abusive earnings management components that serves as a sign of danger in detecting financial statement fraud. This research is important to do, because by understanding the red flags, fraud can be detected earlier so that the parties who use the financial statements can be spared from a lie that may be detrimental to their business and become scandal in the future.

This study aims to examine the correlation between the components of financial statements which are included in the early warning of abusive earnings managementsuch as cash flow and earnings, receivable and revenue, allowance for uncollectible accounts and receivables. This study is done to determine whether the companies that commit financial statement fraud have uncorrelated accounts, because the uncorrelated accounts indicate the efforts of management to tamper with the financial statements.

\section{THEORETICAL BASIS}

\subsection{Financial Statement Fraud}

Financial statement fraud has become a hot topic to discuss since the rise of Enron case that scandalized the world community in the early 2000s. The case of Enron prompted the policy makers to set SOX (SarbanesOxley Act) in 2002, IFAC published ISA 240 (International Standards on Auditing) in March 2001, and AICPA published SAS 99 (Statement on Auditing Standards) in February 2002. Financial statement fraud is a deliberate action or negligence that results in a misleading material misstatement of financial statements, American Institute of Certified Public Accountant (AICPA: 1998). The financial reporting that contains elements of fraud can lead to lower the integrity of financial information. Financial statement fraud is often associated with the failure of auditors to detect it. Auditing Standards section 316 defines financial statement fraud as a form of misstatement or deliberate omission of amounts or disclosure in financial statements to deceive financial statement users.

\subsection{Red Flags}

The termred flags is often used in auditing literature which means a sign of danger, the sign that there is something wrong and needs to be addressed more intensely. Auditors and investigators use the red flags as an indication of potential fraud. The proficiency of auditors and investigators in reading and explaining the signs of danger will increase the possibility of detecting manipulation in financial statements. 
Suartana (2009) stated that information about red flags affects the final assessment of an auditoron an audit case. The implication is that the indication of red flags should obtain a sufficient portion, because it is a region of auditor's responsibilities, and the handling of the red flags would make it possible to detect fraud.

\subsection{Financial Statement Fraud Detection}

Throughout the last decade, public accountants have been criticized widely due to the failure to protect the interests of their investors. In order to give credence to the auditor, Indonesia has made standard on the auditor's responsibilities, that is, Auditing Standards section 110, which states that an auditor is responsible to plan and perform audit to obtain reasonable assurance about whether the financial statements are free from material misstatement caused by either error or fraud. Judging the sequence level of the auditor's responsibilities year by year, in this era, the responsibilities of auditors in uncovering material fraud have actually evolved slowly to be more aggressive, which is in line with the turmoil scandals in capital market. This scalable evolution of thought makes the shift in auditor doctrine from watchdog to bloodhound (Tuanakotta: 2013).

Auditors need to take measures to detect and prevent fraud in the financial statements. There are five factors that can be used by auditors in detecting financial statement fraud, such as through forensic audit approach, GGC (Good Corporate Governance) approach, internal control approach, detection using financial ratios, and earnings management approach.

\subsection{Abusive Earnings Management}

Good earning is a sustainable earning. To achieve the goal, some managers manipulate their earnings in order to look very good in the eyes of the public. This activity is called earnings management. Mulford and Comiskey (2010) define earnings management as the manipulation of accounting with the goal of creating the company's performance in order to look better than it actually is. From the definition, the objective of fraud and earnings management is the same, that is, to manipulate financial statements. If the fraud is beyond GAAP (General Accepted Accounting Principles), the earnings management is within and beyond the limits of GAAP.

Securities and Exchange Commission (SEC) classifies earnings management activities into two different sides. They are:

1. Earnings management in the form of good business practices, that is, the practices that are still within the limits of GAAP (General Accepted Accounting Principles), which is a reasonable problem for the company in managing its earnings.

2. Earnings management in the form of abusive earnings management practices, that is, the practices that generate earnings illusion, in which the management is trying hard to fool the outsiders as if the company were in the best condition. 
Abusive earnings management is used as red flagsto detect fraud.Red flags serve as early warning so that the auditor could be more observant in the areaswhere there are red flags. SEC mentionsthat early warning on the presence of abusive earnings management as stated in the research by Magrath and Weld (2002) related to early warning signs, in whichthere are six correlations that should be considered by investors and auditors related to abusive earnings management, namely

1. Cash flows that are not correlated with earnings.

2. Receivables that are not correlated with revenues.

3. Allowances for uncollectible accounts that are not correlated with receivable.

4. Reserves that are not correlated with balance sheet items.

5. Acquisitions with no apparent business purpose.

6. Earningsthat consistenly and precisely meet analysts expectations.

\subsection{Components of Financial Statements}

This study focuses on allegedly uncorrelated accounts signifying any manipulation in financial statements. Here are the accounts in the accounting that are used as the variables in this study.

\subsubsection{Cash Flow}

Cash flows statement can provide important clues about the company's financial stability and financial solvency (the ability to meet the obligations of the company). In the process of making economic decisions, the financial statement users need to evaluate the company's ability to generate cash and cash equivalent as well as the assurance of its acquisition (the Solar 2012: 45). Cash flows of operating activities are indicators to assess how the company's ability to generate sufficient cash, which can be used to repay loans, maintain the operating capability of the company, pay dividends, and make new investments without relying on external sources of financing. Cash flows from operating activities are primarily derived from the principal revenue-producing activities of the company. Therefore, cash flows are generally derived from transactions and other events that affect the determination of net profit or loss, Statement on Financial Accounting Standards (PSAK) 2, of 2014.

The studies of the correlation between operating cash flow and other accounts in the financial statements have been done by several researchers. Elrod (2010) examined the correlation between cash flows of operating activities and revenue of operating activities. This study tested the null hypothesis in which the uncorrelated accounts are an indication that the management is manipulating the financial statements. The samples in the study are classified into two groups: the companies that are proven to commit fraud (fraud companies) and the companies that are not proven to commit fraud (non-fraud companies) as the comparison companies outside of hypotheses to be tested. The results show that there is a statistical correlation between cash flows of 
operating activities and revenue of operating activities of fraud companies and non-fraud companies. This means that the research results conducted by Elrod reject the null hypothesis.

\subsubsection{Earnings}

Earnings, according to PSAK 1 (2014) is the change in equity during a period resulting from transactions and other events, in addition to the changes resulting from transactions with owners in their capacity as owners. Earning is the most important account for the users of financial statements, especially shareholders, but the high interests of various parties have made the earnings frequently manipulated. Suwarjono (2005: 455) states that, from tax side and financial side, earnings can be defined differently. In terms of tax, earnings is the gross amount or can be interpreted as income, while in terms of finance, earnings is the net amount which is defined as the increased net assets beyond the transaction with the owners. Many expectations about earnings figures often make these accounts manipulated. To know whether the company recognizes the earnings accurately and at the actual period can actually be seen from its correlation with operating cash flow, because the operating cash flows use the cash basis that is not possible to admit the earnings prematurely or distribute the earnings in subsequent periods.

\subsubsection{Receivable}

Receivable is a claim of money, goods, or services to customers or other parties (Surya 2012: 89). According to its source, receivable is classified into two categories: trade receivable and other receivables. Trade receivable includes receivable arising from the sale of products or delivery of services in the normal business activities of the company, while other receivables are receivables arising from transactions outside the normal business activities of the company. Trade receivable and other receivables are expected to be collectible in a single year, or a normal business cycle which is classified as the company's current assets (PSAK No. 9: 1994). Receivable account is an account that is often manipulated because this account determines the occurrence of revenue and earnings. Today, most transactions in the company are done by credit system. Therefore, receivable will be an account that always arises when a sales transaction occurs. Receivable account itself should correlate with income account (when credit sales transaction occurs) and correlate with the account of allowance for uncollectible accounts (when determiningthe receivables in balance sheet accounts after net of depreciation).

\subsubsection{Revenue}

Revenue can be defined from several concepts. From the concept of revenue inflows, revenue is defined as an increase in assets. Meanwhile, from the concept of revenue outflows, revenue is defined as the delivery of products which is measured on the basis of the award for the product, Suwardjono (2005: 393). According to PSAK 23 (2014), revenue is an increase in economic benefits during the accounting period in the form of inflows or 
increases in assets or decreases of liabilities that result in increases in equity, which is not funded by contributions from investors. Problem in the revenues is in the recognition, where the accrual basis allows companies to recognize revenue when the cash has not been received. According to the Financial Accounting Standard, revenue recognition is measured at fair value of the reward received and can be received.

According to Albrecht et al. 2006, most frequently manipulated accounts, in financial statement fraud, are receivable and revenue accounts. These two accounts are very pertinent, and therefore the increase in receivables will be accompanied by the increase in revenue. If the two accounts do not correlate, it indicates that management is recognizing premature revenue or even fictitious income. It is usually related to the company's desire to have a high level of profitability.

\subsubsection{Allowance for Uncollectible Accounts}

Receivable is stated at the gross amount of the bill reduced by the estimated amount of uncollectible account. The gross amount of receivable should continue to be presented in the balance sheet followed by the allowance for uncollectible accounts or estimated amount of uncollectible account. The allowance of collectible account would be a burden for the company. Allowance for receivable account has two methods of approach:income statement approach and balance sheet approach. Companies often take advantage of the flexibility in the regulation of financial reporting, including the flexibility on the estimation of allowance for receivable accounts which causes burden in allowance for receivable, Dechow et al. (1995). The company has a freedom to determine the estimated fair value of receivables, and this is often used by the management to manipulate the financial statements. According to Beneish (1997), the estimate of allowance for receivables is the highest mode in earnings management strategies beyond the limit of GAAP (General Accepted Accounting Principles).

\subsection{Research Hypothesis Development}

Financial statement fraud is detrimental to users. Before being a scandal that brings a broader impact, financial statement fraud must be detected. In dept audit is required to detect the truth on financial statement fraud. But there are some signals that can be read by any users of financial statements about early warning of financial statement manipulation, disclosed by Magrath and Weld (2002), to give red flags to the companies that play their financial figures. Magrath and Weld mention that the companies that commit fraud are indicated to have uncorrelated accounts, indicating that the companies have committed abusive earnings management that led to the financial statement fraud.

\subsubsection{The Absence of Correlation between Cash Flows and Earnings}

Cash flows of operating activities are obtained from the main activity of the company's revenue. Therefore, the cash 
flows of operating activities are derived from transactions and other events that affect the determination of net profit or loss. The correlation between cash flows of operating activities and earnings is very strong. The absence of correlation between cash flows of operating activities and earnings indicates that the company is involved in improper revenue recognition by recognizing the revenue in the wrong period. This even indicates that the company has recorded fictitious sales (Magrath and Weld 2002).

Financial Accounting Standards state that all entities are obliged to prepare their financial statements on an accrual basis, except for statements of cash flows. The basic differences in recording can be used to read any indication of the number-crunching, because the accrual basis is the area that is often used by themanagement to enhance its profit figures. The absence of correlation between cash flows and earnings can serve as red flags to detect any financial statement fraud. Based on the above description, the first hypothesis of this research is as follows:

\section{H1 : Cash Flows are not correlated with Earnings}

\subsubsection{The Absence of Correlation between Receivable and Revenue}

With the development of the business world, people and companies tend to make business transactions using credit payment. Companies seldom use cash transactions because buyers want to take advantage of more time to pay for goods purchased so that the cash flows can be used for other purposes. Meanwhile, for the sellers, credit transaction is used as a tool to attract the buyers. The recognition of receivables is related to the recognition of revenue (Surya 2012: 88), so the increase in accounts receivable will definitely affect the increase in revenue. When these two accounts are not correlated, this indicates that the company has recorded fictitious sales or the company is trying to inflate revenue (Magrath and Weld 2002). Such case was experienced by Lucent Technologies which increased receivables by $49 \%$, while the revenues are only increased by $20 \%$. Based on the above description, the second hypothesis of the research is as follows:

\section{H2 : Receivables are not correlated} with Revenue

\subsubsection{The Absence of Correlation between Allowances for Uncollectible Account and Receivable}

Accounts receivable is assessed and reported in the statement of financial position at net realizable value, that is, the net valuewhich is expected to be received in the form of cash. The determination of net value of accounts receivable requires theestimate of allowance for uncollectible accounts.Analyzing the correlation between accounts receivable and allowance for uncollectible accounts can provide clues on the occurrence of earnings management beyond the boundaries of GAAP (General Accepted Accounting Principles). An increase in the amount of receivables without being accompanied by an increase in the allowance for uncollectible accounts 
provides an indication that the management recognizes revenue early (Magrath and Weld 2002). Likethe case of Lucent and Cendant that loweredtheir accounts of allowance for uncollectible accounts when current revenue and accounts receivable are recorded increases. Based on these descriptions, the third research hypothesis is as follows:

H3 : Allowance for UncollectibleAccounts is not correlated with Receivables

\section{RESEARCH METHODOLOGY \\ 3.1 Research Approach}

This research is using quantitative method by analyzing causality used to describe the effect that becomes the components of financial statements, including early warning on the presence of Abusive Earning Management.

\subsection{Operational Definition Measurement of Variables}

\subsubsection{Independent Variable $(\mathrm{X})$}

Measurement of variables in this study is conducted using the original number of the components of financial statements because this research is a vertical analysis, an analysis of financial statements in the period when the company is proven to commit fraud. This research uses five independent variables including the components of financial statements related to early warning signs of the presence of abusive earnings management:

\section{Cash Flow $\left(\mathrm{X}_{1}\right)$}

In this study, cash flow is seen from operating activities, because the cash flow of operating activities is arising from transactions and events which affect the determination of net profit or loss for the current year. Operational Cash flows are principal revenue-producing activities of the entity and other activities that are not investing and financing activities (SFAS No. 2, 2014).

\section{Earnings $\left(\mathrm{X}_{2}\right)$}

This study uses earnings numbers from the net earnings because net earnings are the value which is actually acquired by the company through its business activity. Profit and loss is total earnings expenses, excluding the components of other comprehensive income (PSAK No. 1, 2014).

\section{Accounts receivable $\left(\mathrm{X}_{3}\right)$}

Accounts receivable is a claim for credit sales to customers. In this study, account receivable is obtained from the net figures of accounts receivable after being deducted by the allowance of account receivable specified by management.

\section{Revenue $\left(\mathrm{X}_{4}\right)$}

Revenue is the gross inflows of economic benefits arising from the ordinary activities of the entity during a period when those inflows result in an increase in equity that is not derived from the contributions of investors (PSAK No. $23,2014)$.

\section{Allowance for Uncollectible Accounts $\left(X_{5}\right)$ Allowance for uncollectible accounts is an analysis of net settlement of accounts receivable to be received in the future, because not all receivables occurred, the repayment can be accepted because of various things.}




\subsection{Sample}

Based on purposive sampling using sample matching method, it is obtained 122 companies, in which 61 companies are indicated to commit fraud (fraud companies) and 61 companies are not indicated to commit fraud (non-fraud companies). The determination of companies which are indicated to commit fraud is based on the annual reports and press release of the Capital Market Supervisory Agency (Bapepam) and Financial Services Authority (OJK) period 2000 - 2014. The details of the sample can be seen in the following table:

Table 3.1

\section{Details of Research Samples}

\begin{tabular}{|l|c|}
\hline Criteria & Number \\
Companies that committed fraud & 97 \\
2000-2014 & $(19)$ \\
Financial companies that & \\
committed fraud 2000-2014 & $(17)$ \\
Companies with incomplete data & \\
Results of sample for fraud & 61 \\
companies & $\begin{array}{l}\text { Non-fraud companies as the } \\
\text { comparison }\end{array}$ \\
\hline Total research samples & $\mathbf{1 2 2}$ \\
\hline
\end{tabular}

Source: Processed data

\subsection{Source of Data}

Data on companies which are indicated to commit fraud are obtained from annual reports and press release of Bapepam and OJK as well as from the request to the OJK Central Office via e-mail.

\subsection{Model Testing}

Model testing in this study is using bivariate correlation test because the research hypothesis is in the form of associative hypothesis. Associative hypothesis is a conjecture about the correlation between the variables in the population to be tested through the correlation between variables in the samples taken from the population, Sugiyono (2013: 224). Before testing the correlation, the first thing to do is to test the normality as a condition of correlation.

\subsubsection{Normality Test}

The purpose of normality test is to test whether confounding variables or residuals have a normal distribution in the correlation models.

The basis for decision making of statistical test is using Kolmogorov-Smirnov Z (1-Sample $\mathrm{K}-\mathrm{S})$ :

$\mathrm{H} 0=$ if $\mathrm{p}$-value $\geq 0.05$ residual data is normally distributed

$\mathrm{H} 1=$ if $\mathrm{p}$-value $<0.05$ residual data is not normally distributed

If the result of normality test of the research variables tends to be abnormal, the Spearman correlation test (parametric statistics) is then used. If the distribution of the data is normal, then it is used Pearson correlation test (parametric statistics). Parametric statistics works based on the assumption that the data of each variable is analyzed based on normal distribution. Therefore, before the researchers use the parametric statistical technique, the normality of the data should be tested first. If the data is not normal, parametric statistics cannot be used, therefore non-parametric statistics should be used then, Sugiyono (2013: 79). 


\subsubsection{Correlation Test}

Correlation test is used to test the hypothesis in this study. The objective is to test the correlation between the variables. This study uses Spearman correlation test because the data distribution from normality test results are not normally distributed. Correlation test for fraud companies is used to answer the research hypotheses, while correlation test for non-fraudulent companies is used as the comparison in seeing the patterns of correlation of the variables without answering the research hypothesis. This is done to see if there are differences in the patterns of correlation between variables in fraud companies and variables in non-fraud companies.

The interpretation of the correlation test can be seen from the significance of correlation (Sig. 2-tailed) with the criteria as follows:

a. If the value of the significance of research result $<0.05$, this means that there is a significant correlation (Ha is accepted).

b. If the value of the significance of research result $>0.05$, this means that there is no significant correlation (H0 is accepted).

To see whether a variable has a strong correlation or not, it can be seen from the correlation coefficient, Young, 1982, in Sulaiman (2002: 136) with the following criteria:

a. $\quad 0.700$ to 1.000 indicates high degrees of association. b. 0.400 to 0.700 indicates substantial degrees of association.

c. 0.200 to 0.400 indicates low degrees of association.

d. 0.000 to 0.200 indicates ignored degrees of association.

\section{RESULTS OF RESEARCH AND DISCUSSION}

\subsection{Normality Test}

The results of normality testusing the Kolmogorov-Smirnov test (K-S) for fraud and non-fraudcompaniesshow that the significance value of all variables is $0.000<0.05$. This can be concluded that the data are not normallydistributed. When the data normality test is not met, then the research is continued by using non-parametric statistics which means that the correlation test is performed using Spearman correlation test.

\subsection{Correlation Test}

To answer the research hypothesis, the correlation test is used to see the correlation between variables. This study uses Spearman correlation test because, based on normality test results, the data are not normally distributed. Correlation test is done four (4) times: (1) Correlation test for fraud companies to answer the research hypothesis. (2) Correlation test for non-fraud companies which serves as comparison in seeing the pattern of correlation without answering the research hypothesis. This is done to see if there are differences in the pattern of correlation between the variables in fraud companies and in non-fraud companies. 
(3) Correlation test which is conducted using the criteria of the types of fraud. (4) Correlation test which is conducted using the criteria of the types of industry. Here are the results of correlation test for fraud and non-fraud companies:

Table 4.1

Results of Correlation Test for Fraudulent Companies: Spearman's Rho

\begin{tabular}{lccccc}
\hline X1 & X3 & $\begin{array}{c}\text { Correlation } \\
\text { Coefficient }\end{array}$ & Explanation & Decision \\
\hline X2 & 0.085 & & 0.222 & Sig. $0.724>0.05$ & Not correlated \\
X4 & & 0.000 & 0.867 & Sig. $0.000<0.05$ & Correlated \\
X5 & & 0.000 & 0.613 & Sig. $0.000<0.05$ & correlated \\
\hline
\end{tabular}

\section{Results of Correlation Test for Non-Fraudulent Companies: Spearman's Rho}

\begin{tabular}{cccccc}
\hline & $\mathrm{X} 1$ & $\mathrm{X} 3$ & $\begin{array}{c}\text { Correlation } \\
\text { Coefficient }\end{array}$ & Explanation & Decision \\
\hline X2 & 0,000 & & 0,684 & Sig. $0.000<0,05$ & Correlated \\
X4 & & 0,000 & 0,893 & Sig. $0,000<0,05$ & Correlated \\
X5 & & 0,000 & 0,696 & Sig. $0,000<0,05$ & Correlated \\
\hline
\end{tabular}

Source: Appendix p. 24.

Description: X1: Cash flow, X2: Earnings, X3: Account receivable, X4: Revenue, X5: Allowance for uncollectible account

\subsubsection{Cash Flow is not Correlated with Earnings}

The results of Spearman's correlation test of the first hypothesis for the companies which are indicated to commit financial statement fraud show that cash flows are not correlated with earnings. Thus it can be said that the first hypothesis is accepted, which means that the absence of correlation between cash flows and earnings can be used as red flags to detect financial statement fraud. It is based on the result of statistics test in Table 4.5 which shows that the correlation between cash flow and earnings has a significance value of 0.085 or more than 0.05 , but when it is seen from the correlation coefficient value of 0.222 , this indicates that cash flows have low correlation with earnings. Results of correlation test of cash flows and earnings for the comparison companies show the significance value of 0.000 . This means that there is a very strong correlation between cash flows and earnings. These results strengthen the acceptance of the first hypothesis.

These results demonstrate empirically the research by Margart and Weld (2002) stating that if the earnings is recognized correctly, the cash flow should closely follow the earnings recognition. If the cash flow and earnings are not interlinked, then there is an indication that the company is inflating the earnings by 
recognizing revenue in wrong period or even recognizing fictitious revenue, because in the earnings recognition, the presentation is using accrual basis, while for the cash flow statement, it is not allowed to use accrual basis, or in other words, the recording of cash flows is using basic cash basis. The use of accrual basis in the earnings recognition is often used by managers to play the earnings figures so as to make the company look in the best condition. By comparing the operating cash flow and net profit of the company, the users of financial statements can see the actual earnings obtained by the company in the current period, because cash flows of operating activities are derived from transactions and other events that affect the determination of net profit or loss. When the growth rate of operating cash flow differs greatly from the growth rate of net profit (uncorrelated), this is an indication / sign that the management is manipulating the company's financial statement.

\subsubsection{Receivable is not Correlated with Revenue}

The results of Spearman's correlation test of the second hypothesis for fraud companies show that receivable is correlated with revenue, with the significant value of 0.000 or less than 0.05 , and a correlation coefficient of 0.867 , indicating a very strong correlation between receivable and revenue. This means that the second hypothesis is rejected. While the results of correlation test for non-fraud companies show the significance value of 0.000 , indicating that receivable and revenue are perfectly
correlated.This can be seen from the correlation coefficient value of 0.893 , which means that the correlation between receivable and revenue is strong. The correlation between receivable and revenue cannot be used as red flags to indicate the occurrence of financial statement fraud.

The results of this study reject empirically the research of Margart and Weld (2002) stating that the uncorrelated increase in receivable and revenue can be a red flag that the management is engaged in creative accounting or the company is performing earnings management practices beyond the borders of GAAP (General Accepted Accounting Principles). The existence of allowance in the recognition of revenue with accrual basis provides reproach to the management to recognize the revenue not in the real period. An increase in receivable without accompanied by an increase in revenue indicates that the company recognizes the revenue that should have been recognized in the previous period. Meanwhile, when the receivable decreases and revenue increases, this indicates that the management is inflating revenue by recording revenue prematurely or even recording fictitious revenues. The important reason in the recognition of false revenue is because the value of revenue will affect earnings, and earnings is a measure which is the most often used by the users of financial statements to assess the condition of the company.

The correlation between receivables and revenues is indeed very strong, where the transaction of receiving revenue in this era is always done using credit system that will 
bring the company's accounts receivables. The correlation between receivable and income cannot be used as red flags because when the management is committing fraud and playing the figures in receivables and revenues, the market will easily recognize that the management is involved in financial statement fraud and violates the labor contracts with the agency (the owner).

\subsubsection{Allowance for Uncollectible Account is not Correlated with Receivables}

The results of Spearman's correlation test of the third hypothesis for fraud companies show that the allowance for uncollectible accounts is correlated with receivable. Thus it can be said that the third hypothesis is rejected, which means that the correlation between the allowance for uncollected accounts and receivable cannot be used as red flags to detect financial statement fraud. This is based on the results of the statistics test in Table 4.5 which shows the correlation between the allowance for uncollectible accounts and receivables for fraud companieshasa significance value of 0.000 and coefficient value of 0.613 . Thus the third hypothesis is rejected because the results of correlation test above show that the allowance for doubtful accounts and accounts receivable are correlated. Meanwhile, the results of correlation test for non-fraud companies show the significance value of 0.000 and coefficient value of 0.696 . From the results of correlation test between fraud companies and non-fraud companies, both claim that the allowance for uncollectible accounts and receivable are substantially correlated.

The results of this study empirically reject the research of Margart and Weld (2002) stating that the absence of correlation between allowance for uncollectible accounts and receivables can provide indication that the management is manipulating the financial statements. Such manipulation intrigues have ever been carried out by Lucent, a manufacturer of telecommunications equipment, and Cedant, a company engaged in real estate. These two companies are indicated to commit financial statement fraud by reducing the reserve for uncollectible debt and increasing the accounts receivable, this is done to recognize a greater income than it actually is.

The correlation between allowance for uncollectible accounts and receivable cannot be used as red flags to detect financial statement fraud because the account of allowance for uncollectible accounts always follows the value of accounts receivable, so the two are stated to have a close correlation. Allowance for uncollectible accounts occurs when the management believes that the receivable is uncollectible or the account receivables have a lifespan of more than one year.

\subsection{Correlation Test Confirmation for Strengthening Hypothesis by Sorting based on the Types of Fraud}

Correlation test is then performed to distinguish the research samples based on thetypes of fraud.The results of this correlation test are not to answer the research hypothesis, 
but they are used to see whattype of fraudthat hasuncorrelated components of financial statement.Thisis doneso that the market can specificallyuse the results of this correlation test as red flags to detect financial statement fraud.

Table 4.2

The Results of Correlation Test for Fraud and Non-Fraud Companies

Based on the Type of Fraud: Spearman's Rho

\begin{tabular}{|c|c|c|c|c|c|}
\hline \multicolumn{6}{|c|}{ FRAUD COMPANIES } \\
\hline \multicolumn{6}{|c|}{ Fraud in Financial Manipulation } \\
\hline & $\mathrm{X} 1$ & $\mathrm{X} 3$ & $\begin{array}{l}\text { Correlation } \\
\text { Coefficient }\end{array}$ & Explanation & Decision \\
\hline $\mathrm{X} 2$ & 0.229 & & 0.289 & Sig. $0.229>0.05$ & Not correlated \\
\hline $\mathrm{X} 4$ & & 0.000 & 0.930 & Sig. $0.000<0.05$ & Correlated \\
\hline $\mathrm{X} 5$ & & 0.000 & 0.950 & Sig. $0.000<0.05$ & Correlated \\
\hline \multicolumn{6}{|c|}{ Fraud in Presenting Financial Statement (G.VII) } \\
\hline & $\mathrm{X} 1$ & $\mathrm{X} 3$ & $\begin{array}{c}\text { Correlation } \\
\text { Coefficient }\end{array}$ & Explanation & Decision \\
\hline $\mathrm{X} 2$ & 0.240 & & 0.301 & Sig. $0.240>0.05$ & Not correlated \\
\hline $\mathrm{X} 4$ & & 0.000 & 0.770 & Sig. $0.000<0.05$ & Correlated \\
\hline $\mathrm{X} 5$ & & 0.034 & 0.515 & Sig. $0.034<0.05$ & Correlated \\
\hline
\end{tabular}

Other Frauds

\begin{tabular}{|c|c|c|c|c|c|}
\hline & $\mathrm{X} 1$ & $\mathrm{X} 3$ & $\begin{array}{l}\text { Correlation } \\
\text { Coefficient }\end{array}$ & Explanation & Decision \\
\hline $\mathrm{X} 2$ & 0.509 & & 0.138 & Sig. $0.509>0.05$ & Not correlated \\
\hline $\mathrm{X} 4$ & & 0.000 & 0.849 & Sig. $0.000<0.05$ & Correlated \\
\hline $\mathrm{X} 5$ & & 0.238 & 0.245 & Sig. $0.238>0.05$ & Not correlated \\
\hline \multicolumn{6}{|c|}{ NON-FRAUD COMPANIES } \\
\hline \multicolumn{6}{|c|}{ Fraud in Financial Manipulation } \\
\hline & $\mathrm{X} 1$ & $\mathrm{X} 3$ & $\begin{array}{l}\text { Correlation } \\
\text { Coefficient }\end{array}$ & Explanation & Decision \\
\hline $\mathrm{X} 2$ & 0.041 & & 0.472 & Sig. $0.041<0.05$ & Correlated \\
\hline $\mathrm{X} 4$ & & 0.000 & 0.853 & Sig. $0.000<0.05$ & Correlated \\
\hline $\mathrm{X} 5$ & & 0.017 & 0.542 & Sig. $0.017<0.05$ & Correlated \\
\hline \multicolumn{6}{|c|}{ Fraud in Presenting Financial Statement (G.VII) } \\
\hline & $\mathrm{X} 1$ & $\mathrm{X} 3$ & $\begin{array}{l}\text { Correlation } \\
\text { Coefficient }\end{array}$ & Description & Decision \\
\hline $\mathrm{X} 2$ & 0.000 & & 0.775 & Sig. $0.000<0.05$ & Correlated \\
\hline $\mathrm{X} 4$ & & 0.000 & 0.904 & Sig. $0.000<0.05$ & Correlated \\
\hline $\mathrm{X} 5$ & & 0.000 & 0.836 & Sig. $0.000<0.05$ & Correlated \\
\hline
\end{tabular}




\begin{tabular}{lccccc}
\hline \multicolumn{6}{c}{ Other Frauds } \\
\hline & \multirow{2}{*}{ X1 } & X3 & $\begin{array}{c}\text { Correlation } \\
\text { Coefficient }\end{array}$ & Explanation & Decision \\
\hline X2 & 0.000 & & 0.693 & Sig. $0.000<0.05$ & Correlated \\
X4 & & 0.000 & 0.885 & Sig. $0.000<0.05$ & Correlated \\
X5 & & 0.000 & 0.785 & Sig. $0.000<0.05$ & Correlated \\
\hline
\end{tabular}

Source: Processed Data.

Description: X1: Cash flows, X2: Earnings, X3: Account receivable, X4: Revenue, X5: Allowance for uncollectible receivables

\subsubsection{Results of Correlation Test for Market Manipulation}

Financial statement fraud has various modes. One of them is by way of manipulating the market. It is the fraud which is commonly committed by the management with the aim to increase the stock price in capital markets. Here are the results of correlation test for fraud in market manipulation:

1. The absence of correlation between cash flow and earnings in fraud companies shows the significance value of $0.229>0.05$ (uncorrelated), and in non-fraud companies of $0.041<0.05$ (correlated).

2. The absence of correlation between receivable and revenue in fraud companies shows the significance value of $0.000<0.05$ (correlated), and in non fraud companies of $0.000<0.05$ (correlated).

3. The absence of correlation between allowance for uncollectible account and receivable in fraud companies shows the significance value of $0.000<0.05$ (correlated), and in non-fraud companies of $0.017<0.05$ (correlated).

\subsubsection{Results of Correlation Testfor Financial Statement Presentation Fraud (G.VII)}

Financial statement presentation fraud is one type of fraud most commonly committed by the management in order to embellish the financial statements with the aim of showing the best performance of the company to the public. This fraud is usually committed by displaying overstatement / understatement of accounts in the financial statements that leads to the increase or decrease in corporate profits. Here are the results of the correlation test for financial statement presentation fraud:

1. The absence of correlation between cash flow and earnings in fraud companies shows the significance value of $0.240>0.05$ (uncorrelated), and in non-fraud companies of $0.000<0.05$ (correlated).

2. The absence of correlation between receivable and revenue in fraud companies shows the significance value of $0.000<0.05$ (correlated), and in non-fraud companies of $0,000<0.05$ (correlated).

3. The absence of correlation between allowance for uncollectible accounts and receivable in fraud companies shows the significance value of $0.034<0.05$ (correlated), and in non-fraud companies of $0.000<0.05$ (correlated). 


\subsubsection{Results of Correlation Test for Frauds other than Market Manipulation and G.VII.}

Other frauds here include conflict of interest in affiliation and transactions, material transactions and changes in major business activities, disclosure of information for issuers that are filed for bankruptcy and other types of violations of Indonesian capital market regulations. The weakness ofthe correlation test results on this fraud is the existence of several companies whose types of fraud are not published by the Capital Market Supervisory Agency (Bapepam) and Financial Services Authority (OJK). Here are the results of correlation test for companies which are proven to have committed fraud other than market manipulation and G.VII:

1. The absence of correlation between cash flow and earnings in fraud companies shows the significance value of $0.509>0.05$ (uncorrelated), and in non-fraud companies with the significance value of $0.000<0.05$ (correlated).

2. The absence of correlation between receivable and revenue in fraud companies shows the significance value of $0.000<0.05$ (correlated), and in non-fraud companies with the significance value of $0,000<0.05$ (correlated).

3. The absence of correlation between allowance for uncollectible accounts and receivablein fraud companies with the significance value of $0.0238>0.05$ (uncorrelated), and in non-fraud companies with the significance value of $0.000<0.05$ (correlated).

\subsection{Correlation Test Confirmation toStrengthen the Hypothesis by Selecting the Correlation Test Based on Types of Industry}

The next correlation test is performed to distinguish the research sample based on the types of industry, such as the correlation test based onthe types offraud.The results of correlation test based on the types of industry are not to answer the research hypothesis. These results areused to see what type of industry which hasuncorrelated components of financial statements.

\subsubsection{Results of Correlation Test in Manufacturing Industry}

Manufacturing company is a company that manages the raw materials into goods that ready for sale. The number of stages in the production process of manufacturing companies makes the financial statements of this type of industry more complicated than those of other companies. Here are the results of the correlation test in manufacturing companies

1. The absence of correlation between cash flow and earnings in fraud companies shows the significance value of $0.615>0.05$ (uncorrelated), and in non-fraud companies with the significance value of $0.000<0.05$ (correlated).

2. The absence of correlation between receivable and revenue in fraud companies shows the significance value of $0.000<0.05$ (correlated), and in non-fraud companies with the significance value of $0,000<0.05$ (correlated). 
3. Theabsence of correlation between allowance for uncollectible accounts and receivable in fraud companies shows the significance value of $0.000<0.05$ (correlated), and in non-fraud companies with the significance value of $0.000<0.05$ (correlated).

\subsubsection{Results of Correlation Test in Non Financial Service Industry}

Service industry is a type of business that generates revenue by handing over services to customers. The correlation test is conducted in service companies other than financial service companies. Here are the results of correlation test in non-financial service companies:
1. The absence of correlation between cash flow and earnings in fraud companies shows the significance value of $0.033<0.05$ (correlated), and in non-fraud companies of $0.000<0.05$ (correlated).

2. The absence of correlation between receivable and revenue in fraud companies shows the significance value of $0.000<0.05$ (correlated), and in non-fraud companies of $0,000<0.05$ (correlated).

3. The absence of correlation between allowance for uncollectible accounts and receivable in fraud companies shows the significance value of $0.000<0.05$ (correlated), and in non-fraud companies of $0.000<0.05$ (correlated).

Table 4.3

Results of Correlation Test in Fraud and Non-Fraud Companies

Based on Type of Industry: Spearman's Rho

\begin{tabular}{|c|c|c|c|c|c|}
\hline \multicolumn{6}{|c|}{ FRAUD } \\
\hline \multicolumn{6}{|c|}{ Manufacturing Industry } \\
\hline & $\mathrm{X} 1$ & $\mathrm{X} 3$ & $\begin{array}{c}\text { Correlation } \\
\text { Coefficient }\end{array}$ & Explanation & Decision \\
\hline $\mathrm{X} 2$ & 0.615 & & 0.092 & Sig. $0.615>0.05$ & Not correlated \\
\hline $\mathrm{X} 4$ & & 0.000 & 0.921 & Sig. $0.000<0.05$ & Correlated \\
\hline $\mathrm{X} 5$ & & 0.000 & 0.647 & Sig. $0.000<0.05$ & Correlated \\
\hline \multicolumn{6}{|c|}{ Non Financial Services Industry } \\
\hline & $\mathrm{X} 1$ & X3 & $\begin{array}{l}\text { Correlation } \\
\text { Coefficient }\end{array}$ & Explanation & Decision \\
\hline $\mathrm{X} 2$ & 0.033 & & 0.397 & Sig. $0.033<0.05$ & Correlated \\
\hline $\mathrm{X} 4$ & & 0.000 & 0.790 & Sig. $0.000<0.05$ & Correlated \\
\hline $\mathrm{X} 5$ & & 0.000 & 0.618 & Sig. $0.000<0.05$ & Correlated \\
\hline \multicolumn{6}{|c|}{ NON FRAUD } \\
\hline \multicolumn{6}{|c|}{ Manufacturing Industry } \\
\hline & $\mathrm{X} 1$ & $\mathrm{X} 3$ & $\begin{array}{l}\text { Correlation } \\
\text { Coefficient }\end{array}$ & Explanation & Decision \\
\hline $\mathrm{X} 2$ & 0,001 & & 0,541 & Sig. $0.001>0,05$ & Not correlated \\
\hline
\end{tabular}




\begin{tabular}{|c|c|c|c|c|c|}
\hline $\mathrm{X} 4$ & & 0,000 & 0,805 & Sig. $0,000<0,05$ & Correlated \\
\hline $\mathrm{X} 5$ & & 0,000 & 0,636 & Sig. $0,000<0,05$ & Correlated \\
\hline \multicolumn{6}{|c|}{ Non Financial Services Industry } \\
\hline & $\mathrm{X} 1$ & $\mathrm{X} 3$ & $\begin{array}{c}\text { Correlation } \\
\text { Coefficient }\end{array}$ & Explanation & Decision \\
\hline $\mathrm{X} 2$ & 0.000 & & 0.809 & Sig. $0.000<0.05$ & Correlated \\
\hline $\mathrm{X} 4$ & & 0.000 & 0.927 & Sig. $0.000<0.05$ & Correlated \\
\hline $\mathrm{X} 5$ & & 0.000 & 0.767 & Sig. $0.000<0.05$ & Correlated \\
\hline
\end{tabular}

Source: Processed Data.

Description: X1: Cash flow, X2: earnings, X3: Receivable, X4: Revenue, X5: Allowance for uncollectible account

\section{CONCLUSION, LIMITATION, AND SUGGESTION}

\subsection{Conclusion}

Based on the results of research and discussion in the previous chapter, the conclusions of this study are as follows:

1. Cash flow and earnings are not correlated. This means that the absence of correlation between cash flow and earnings can be used as red flags to detect financial statement fraud.

2. Receivables and revenue are correlated. This means that the existence of correlationbetween receivables and revenues cannot be used as red flags to detect financial statement fraud.

3. Allowance for uncollectible accounts and receivable are correlated. This means that the existence of correlation between allowance for uncollectible accounts and receivables cannot be used as red flags to detect financial statements fraud.

\subsection{Limitation}

The limitations of this study are:

1. This study only uses vertical analysisand does not includehorizontal analysis.

2. There are several types of fraud committed by companies which are not published by the Capital Market Supervisory Agency (Bapepam) and Financial Services Authority (OJK).

\subsection{Suggestion}

It is suggested that further research use horizontal analysis on companies which are proven to commit fraud, that is, by using delta numbers at least 3 years prior to the occurrence of fraud and three years after the occurrence of fraud.

\section{REFERENCES}

American Institute of Certified Public Accountants. 2002. Statement of Auditing Standards No. 99 Consideration of Fraud in a Financial Statment Audit. New York: AICPA. 
American Institute of Certified Public Accountans (AICPA). 1998. CPA Vision: 2001 and Beyond. New York: AICPA.

Association of Certified Fraud Examiners. 2002. Report to Nation ACFE.

Association of Certified Fraud Examiners. 2012.

Report to The Nations on Occupational Fraud and Abuse.

Association of Certified Fraud Examiners. 2014.

Report to The Nations on Occupational Fraud and Abuse.

Badan Pengawas Pasar Modal. Annual Report Tahun 2000, 2001, 2002, 2003, 2004, 2005, 2007, 2008, 2009, 2010, 2011, 2012.

Badan Pengawas Pasar Modal. 2001a. Press Relase Bapepam 5 Febuari 2001.

Badan Pengawas Pasar Modal. 2001b. Press Relase Bapepam 23 Maret 2001.

Badan Pengawas Pasar Modal. 2001c. Press Relase Bapepam 26 April 2001.

Badan Pengawas Pasar Modal. 2001d. Press Relase Pengenaan Sanksi atas Kasus Perdagangan Saham PT H.M Sampoerna Tbk.

Badan Pengawas Pasar Modal. 2002a. Press Relase Bapepam 18 Juni 2002.

Badan Pengawas Pasar Modal. 2002b. Press Relase Bapepam 8 Nopember 2002.

Badan Pengawas Pasar Modal. 2002c. Press Relase Bapepam 22 Desember 2002.
Badan Pengawas Pasar Modal. 2002d. Press Relase Bapepam Hasil Pemeriksaan Kasus Divestasi Saham PT ISAT.

Badan Pengawas Pasar Modal. 2004. Press Relase Bapepam Hasil Pemeriksaan PT Indofarma Tbk.

Badan Pengawas Pasar Modal. 2005. Press Relase Bapepam 23 Nopember 2005.

Badan Pengawas Pasar Modal. 2007a. Press Relase Bapepam Hasil Pemeriksaan Kasus PT Agis. 17 Desember 2007.

Badan Pengawas Pasar Modal. 2007b. Press Relase Bapepam Hasil Pemeriksaan Kasus PT SUGI dan PT ARTI. 17 Desember 2007.

Badan Pengawas Pasar Modal. 2007c. Press Relase Bapepam 7 Desember 2007.

Badan Pengawas Pasar Modal. 2007d. Press Relase Bapepam Hasil Penelahaan Transaksi Divestasi PT Medco Energi International Tbk.

Beneish, M. 1997. Detecting GAAP, Violation: Implications For Assessing Earnings Management Among Firms With Extreme Financial Performance. Journal of Accoungting and PublicPolicy, 16, 271-309.

Dechow et al. 1995. Detecting Earning Management. The Accounting Review, 70, 193-225.

Elrod, Henry, dan Gorhum, Megan. 2010. Fraudulent Financial Reporting and Cash Flows. Journal of Finance and Accountancy. 
Healy, P dan Wahlen J. 1999. A Riview Of The Earnings Management Literature And Its Implication For Standard Setting. Accounting Horizon 12(4).

IAI, 1994. Pernyataan Standar Akuntansi Keuangan No. 9: Penyajian Aktiva Lancar Dan Kewajiban Jangka Pendek.

IAI. 2001. Standar Audit Seksi 110: Tanggung Jawab dan Fungsi Auditor Independen. Jakarta.

IAI. 2001. Standar Audit Seksi 316: Pertimbangan atas Kecurangan dalam Audit Laporan Keuangan. Jakarta.

IAI. 2014. Pernyataan Standar Akuntansi Keuangan No.1 (Revisi 2009): Penyajian Laporan Keuangan. Jakarta.

IAI, 2014. Peryataan Standar Akuntansi Keuangan No.2 (Revisi 2009): Laporan Arus Kas. Jakarta.

IAI, 2014. Pernyataan Standar Akuntansi Keuangan No. 23 (Revisi 2009): Pendapatan.

Magrath and Weld. 2002. Abusive Earning Management And Early Warning Signs. The CPA Jurnal, 72 (8) (2002), pp. 50-54. Mulford, Charless W, dan Eugene E. Comiskey. The Financial Number Game: Detecting Creative Accounting Practices. www. wiley.com.

Nugraha. Noval dan Henny, Deliza. 2015. Pendeteksian Laporan Keuangan Melalui Faktor Resiko Tekanan dan Peluang. e-Jurnal Akuntansi Trisakti. Volume 2 Nomor. 1 Februari 2015. Hal. 29-48.
Otoritas Jasa Keuangan. 2013. Annual Report Tahun 2013.

Rezaee, Zabihollah dan Richard Riley. 2010. Financial Statment Fraud Prevention and Detection, 2nd Edition. Ney Jersey. John Wiley \& Sons Inc.

Suartana, I Wayan. 2009. Pengalaman Audit, Red flags, dan Urutan Bukti. Jurnal Maksi, Vol 9 No.2 Agustus, hal. 190-202.

Sugiyono. 2013. Statistika untuk Penelitian. Bandung: Alfabeta

Sulaiman, Wahid. 2003. Statistik NonParametrik, Contoh Kasus dan Pemecahanya dengan SPSS. Yogyakarta: Andi Yogyakarta.

Surya, Raja. 2012. Akuntansi Keuangan Versi IFRS+. Yogyakarta:Graha Ilmu.

Suwardjono. 2005. Teori Akuntansi: Perekayasaan Pelaporan Keuangan. Yogyakarta: BPFE-Yogyakarta.

Tuanakotta, M Theodarus. 2013. Mendetaksi Manipulasi Laporan Keuangan. Jakarta: Salemba Empat. 
Handayani, Tarjo, Yuni Rimawati : Correlation of Financial Statement Components.....

\section{Appendix \\ Results of Normality Test for Fraud Companies}

One-Sample Kolmogorov-Smirnov Test

\begin{tabular}{|c|c|c|c|c|c|c|}
\hline & & Cash Flow & Earnings & Receivable & Revenue & $\begin{array}{c}\text { Allowance for } \\
\text { uncollectible accounts }\end{array}$ \\
\hline \multicolumn{2}{|l|}{$\mathrm{N}$} & 61 & 61 & 61 & 61 & 61 \\
\hline \multirow{3}{*}{$\begin{array}{l}\text { Normal } \\
\text { Parameters }{ }^{\mathrm{a}, \mathrm{b}}\end{array}$} & Mean & 490746693072.85 & -59952293655.33 & 550353070553.34 & 2536121962866.98 & 113462391406.50820 \\
\hline & $\begin{array}{l}\text { Std. } \\
\text { Deviation }\end{array}$ & 1808342564488.367 & 1539534464477.141 & 1043389235436.062 & 4413335008951.514 & 539087764727.864900 \\
\hline & Absolute & .333 & .306 & .322 & .305 & .451 \\
\hline \multirow{2}{*}{$\begin{array}{l}\text { Most Extreme } \\
\text { Differences }\end{array}$} & Positive & .333 & .289 & .322 & .305 & .451 \\
\hline & Negative & -317 & -.306 & -.300 & -.283 & -.417 \\
\hline \multicolumn{2}{|c|}{ Kolmogorov-Smirnov $Z$} & 2.602 & 2.389 & 2.514 & 2.384 & 3.526 \\
\hline \multicolumn{2}{|c|}{ Asymp. Sig. (2-tailed) } & .000 & .000 & .000 & .000 & .000 \\
\hline
\end{tabular}

a. Test distribution is Normal.

b. Calculated from data.

\section{Results of Normality Test for Non-Fraud Companies}

One-Sample Kolmogorov-Smirnov Test

\begin{tabular}{|c|c|c|c|c|c|c|}
\hline & & Cash flow & Earnings & Receivable & Revenue & $\begin{array}{c}\text { Allowance for } \\
\text { uncollectible account }\end{array}$ \\
\hline \multicolumn{2}{|c|}{$\mathrm{N}$} & 61 & 61 & 61 & 61 & 61 \\
\hline \multirow{3}{*}{$\begin{array}{c}\text { Normal } \\
\text { Parameters }{ }^{\mathrm{a}, \mathrm{b}}\end{array}$} & Mean & 421067662129.46 & 292372270304.93 & 434441336653.72 & 3838524880104.51 & 22113398784.00000 \\
\hline & $\begin{array}{c}\text { Std. } \\
\text { Deviation }\end{array}$ & 1159257017283.875 & 821432890281.924 & 771964224284.682 & 9521026652751.145 & 64956450437.653940 \\
\hline & Absolute & .351 & .332 & .309 & .343 & .367 \\
\hline \multirow{2}{*}{$\begin{array}{l}\text { Most Extreme } \\
\text { Differences }\end{array}$} & Positive & .351 & .332 & .309 & .335 & .358 \\
\hline & Negative & -.303 & -.291 & -.287 & -.343 & -.367 \\
\hline \multicolumn{2}{|c|}{ Kolmogorov-Smirnov Z } & 2.742 & 2.592 & 2.413 & 2.683 & 2.865 \\
\hline \multicolumn{2}{|c|}{ Asymp. Sig. (2-tailed) } & .000 & .000 & .000 & .000 & .000 \\
\hline
\end{tabular}

a. Test distribution is Normal.

b. Calculated from data.

\section{Results of Correlation Test for Fraud Companies}

The Absence of Correlation between Cash Flow and Earnings

\begin{tabular}{|c|c|c|c|c|}
\hline & & & Cash flow & Earnings \\
\hline \multirow{6}{*}{ Spearman's rho } & \multirow{3}{*}{ Cash flow } & Correlation Coefficient & 1.000 & .222 \\
\hline & & Sig. (2-tailed) & . & .085 \\
\hline & & $\mathrm{N}$ & 61 & 61 \\
\hline & \multirow{3}{*}{ Earnings } & Correlation Coefficient & .222 & 1.000 \\
\hline & & Sig. (2-tailed) & .085 & . \\
\hline & & $\mathrm{N}$ & 61 & 61 \\
\hline
\end{tabular}




\section{The Absence of Correlation Between Receivable and Revenue}

\section{Correlations}

\begin{tabular}{|ccl|c|c|}
\hline & & Receivable & Revenue \\
\hline \multirow{4}{*}{ Spearman's rho } & \multirow{3}{*}{ Receivable } & Correlation Coefficient & 1.000 & $.867^{* *}$ \\
& & Sig. (2-tailed) &. & .000 \\
& & $\mathrm{~N}$ & 61 & 61 \\
& & Correlation Coefficient & $.867^{* *}$ & 1.000 \\
& Revenue & Sig. (2-tailed) & .000 &. \\
& & $\mathrm{~N}$ & 61 & 61 \\
\hline
\end{tabular}

**. Correlation is significant at the 0.01 level (2-tailed).

\section{The Absence of Correlation Between Allowance for Uncollectible Account and Receivable}

\section{Correlations}

\begin{tabular}{|lll|c|c|}
\hline & & Receivable & $\begin{array}{c}\text { Allowance for } \\
\text { uncollectible } \\
\text { account }\end{array}$ \\
\hline & \multirow{3}{*}{ Receivable } & Correlation & 1.000 & $.613^{* *}$ \\
& & Coefficient & & .000 \\
Spearman's rho & & Sig. (2-tailed) &. & 61 \\
& & $\mathrm{~N}$ & 61 & $.613^{* *}$ \\
& Allowance for & Correlation & 1.000 \\
& uncollectible account & Coefficient & .000 &. \\
& & Sig. (2-tailed) & 61 & 61 \\
\hline
\end{tabular}

**. Correlation is significant at the 0.01 level (2-tailed).

\section{Results of Correlation Test for Non-Fraud Companies}

\section{The Absence of Correlation Between Cash flow and Earnings}

\section{Correlations}

\begin{tabular}{|lll|r|r|}
\hline & & Cash flow & Earnings \\
\hline \multirow{4}{*}{ Spearman's rho } & & Correlation Coefficient & 1.000 & $.684^{* *}$ \\
& &. & .000 \\
& & Sig. (2-tailed) & 61 & 61 \\
& & $\mathrm{~N}$ & $.684^{* *}$ & 1.000 \\
& Earnings flow & Correlation Coefficient & .000 &. \\
& & Sig. (2-tailed) & 61 & 61 \\
& $\mathrm{~N}$ & &
\end{tabular}

**. Correlation is significant at the 0.01 level (2-tailed). 


\section{The Absence of Correlation Between Receivable and Revenue}

\section{Correlations}

\begin{tabular}{|lll|c|c|}
\hline & & & Receivable & Revenue \\
\hline & \multirow{4}{*}{ Receivable } & Correlation Coefficient & 1.000 & $.893^{* *}$ \\
& & Sig. (2-tailed) &. & .000 \\
& $\mathrm{~N}$ & 61 & 61 \\
& & Correlation Coefficient & $.893^{* *}$ & 1.000 \\
& \multirow{2}{*}{ Revearman's rho } & Sig. (2-tailed) & .000 &. \\
& & $\mathrm{~N}$ & 61 & 61 \\
\hline
\end{tabular}

**. Correlation is significant at the 0.01 level (2-tailed).

\section{The Absence of Correlation Between Allowance for Uncollectible Account and Receivable}

\section{Correlations}

\begin{tabular}{|lll|c|c|}
\hline & & Receivable & $\begin{array}{c}\text { Allowance for } \\
\text { uncollectible } \\
\text { account }\end{array}$ \\
\hline & Receivable & Correlation & 1.000 & $.696^{* *}$ \\
Spearman's rho & & $\begin{array}{l}\text { Coefficient } \\
\text { Sig. (2-tailed) }\end{array}$ &. & .000 \\
& Allowance for & $\mathrm{N}$ & 61 & 61 \\
& Correlation & $.696^{* *}$ & 1.000 \\
& Coefficient & .000 &. \\
& Sig. (2-tailed) & 61 & 61 \\
\hline
\end{tabular}

**. Correlation is significant at the 0.01 level (2-tailed). 